\title{
DATING AND INTERPRETATION OF RECENT CLASTIC SEDIMENTS IN AN URBAN CAVE
}

\author{
Evan A. Hart ${ }^{1}$
}

\begin{abstract}
Capshaw Cave functions as a major stormwater runoff channel for the city of Cookeville, Tennessee, receiving inputs from several large sinkholes. Sediments deposited in the cave reflect the history of erosion and runoff from the city as it grew over the last century. At various locations in the cave, $\sim 1 \mathrm{~m}$ thick sequences of flood-deposited, laminated fine sediments were observed along the modern stream. Alternating laminations observed in the upper $\sim 40 \mathrm{~cm}$ of the sediment profile varied between $0.5 \mathrm{~cm}$ thick (10Y $7 / 6$ yellow, fine sand) and $2.0 \mathrm{~cm}$ thick (10Y $3 / 2$ very dark grayish brown silty sand) layers. Based on measurements of ${ }^{137} \mathrm{Cs}$ activity, the upper $35 \mathrm{~cm}$ of sediment was deposited between 1963 (the peak year of ${ }^{137} \mathrm{Cs}$ fallout from nuclear testing) and 2013 (the year samples were collected), at an average rate of $0.7 \mathrm{~cm} \mathrm{y}^{-1}$. A total of 23 alternating pairs of layers indicate an average flood recurrence interval of $\sim 2.2$ years between 1963 and 2013. Total $\mathrm{Pb}$ concentrations measured in cave sediments showed a peak at the $45 \mathrm{~cm}$ depth, suggesting that sediments above this level were deposited after the decline in $\mathrm{Pb}$ emissions in the 1970s, and showing general agreement with the timing of deposition suggested by ${ }^{137} \mathrm{Cs}$. Below $40 \mathrm{~cm}$, the dark silty sand layers were fewer in number and increased in thickness (up to $10 \mathrm{~cm}$ ), possibly due to changes in cave hydrology or sediment erosion from the surrounding watershed. These findings suggest that, before the 1960s, sedimentation rates were higher and floods were less frequent. After the 1960s, sedimentation rates decreased and floods became more common, probably as a result of urbanization in the watershed.
\end{abstract}

\section{INTRODUCTION}

Cave deposits are important paleo-environmental records and include 1) chemical deposits (speleothems); 2) clastic sediments (fine-grained infill); 3) breakdown (Bosch and White, 2004); and 4) biologic accumulations (e.g., bat guano) (Onac et al., 2015). The potential of speleothems as paleo-environmental records is well-established (Spötl and Mangini 2002; Drysdale et al., 2006; Meyer et al., 2008; Asmerom et al., 2010; Boch et al., 2011; Badertscher et al., 2014), also see excellent reviews in McDermott (2004), Sasowsky and Mylroie (2007), and White (2007). However, clastic cave sediments have received less attention in the scientific literature and their potential as paleo-environmental proxies remains under-utilized. Clastic cave sediments may be derived from external (allogenic) sources or may originate from within the cave itself (autogenic). The protected environment inside caves may preserve intact sequences of clastic sediment, which are not typically well-preserved outside caves, for example on floodplains. Some caves contain clastic sediment sequences deposited by main valley rivers that overflow into them or simply by cave streams that bring sediment through the karst system. Clastic cave sediments have been dated using cosmogenic isotopes and paleomagnetism to estimate long-term river incision rates (Sasowsky et al., 1995, Granger et al., 2001, Stock et al., 2004). Estimating river incision rates is usually done by dating sediments found in caves along valley walls some height above the modern stream level, and then comparing the age of these sediments to younger sediments preserved in caves at lower elevations.

Studies of more recent clastic sediments have sought to better understand sediment transport in caves and to identify allogenic sediment pollution sources (Mahler et. al 1998; Mahler and Lynch, 1999; Modrá et al., 2017). Dogwiler and Wicks (2004) estimated that up to $85 \%$ of stream substrates in some Missouri and Kentucky caves can be transported during flows having relatively short return periods ( $<1$ year). Other work has focused on the lithology, grain size, and roundness of clastic sediments in caves and related these to sediment provenance (Bull, 1978, 1981; Brinkman and Reeder, 1995). Gillieson (1986) showed that clastic sediments formed diamictons in some New Guinea caves, and that these sediments originated as debris flows from allogenic source areas.

Paleoclimate and paleoenvironmental studies have successfully applied several dating methods to cave sediments including U-Th dating of speleothems (Thompson et al., 1976), paleomagnetism of clastic sediments (Sasowsky et al., 1995), magnetic susceptibility (Šroubek et al., 2001; Šroubek et al., 2007), cosmogenic isotope analysis of cave gravels (Stock, et al., 2004), OSL (optically stimulated luminescence) (Clark-Balzan, et al., 2012), ${ }^{14} \mathrm{C}$ (Surić, et al., 2016), as well as pollen and ${ }^{13} \mathrm{C}$ analysis of organic material extracted from bat guano (Onac et al., 2015). For younger cave sediments deposited over the last few centuries, a suite of other dating methods were tested. Feist (2017) used the isotope ${ }^{210} \mathrm{~Pb}$ to date recent ( $\sim 100$ years) sediments contaminated with heavy metals in Hidden River Cave, Kentucky. Very recent sedimentation (two to three months) in caves has been traced using ${ }^{7} \mathrm{Be}$ (Broderick et al., 2017).

${ }^{1}$ Department of Earth Sciences, Tennessee Tech University, Cookeville, TN 38505; ehart@tntech.edu 
The fallout nuclide ${ }^{137} \mathrm{Cs}$, generated by atomic testing in the mid-1900s, has been used to date cave sediments deposited since that period (Stanton et al., 1992; Klimchouk and Gudzenko, 1996; Curry, 2003). Cesium-137 is a radioactive isotope and fission byproduct, having a half-life of 30.17 years (Poreba, 2006). Atomic testing beginning in the 1950s released radioactive ${ }^{137} \mathrm{Cs}$ into the atmosphere around the globe (Walling and He, 1999). The resulting fallout of ${ }^{137} \mathrm{Cs}$ was incorporated into surface soils and water bodies throughout most of the world, reaching a peak in 1963 (Zhang, et al., 2016). Cesium-137 has been used widely to date lake sediments by assuming that the peak ${ }^{137}$ Cs activity in a lake sediment core is equivalent to the year 1963, the peak year of atomic testing.

In the United States, $\mathrm{Pb}$ emissions, mostly from leaded gasoline vehicles, reached a peak in the 1970s and declined after being phased out of use (USEPA, 2000). The peak and decline of $\mathrm{Pb}$ emissions can be seen in $\mathrm{Pb}$ concentrations measured in lake sediments (Callender and Van Metre, 1997; Juracek and Ziegler, 2006). In this study, ${ }^{137} \mathrm{Cs}$ and total $\mathrm{Pb}$ are used to investigate the timing of flood-deposited sediments in an urban cave system. Whatever method is used to date cave sediments, care should be taken to assure that site-specific conditions are consistent with the assumptions of the technique. For example, Schiegl et al. (1996) found that waterlogging may lead to significant chemical alteration of cave sediments, making dating and interpretation problematic.

\section{STUDY AREA}

The study area is located on the East Highland Rim, a low plateau (280-340 m.a.s.I.) located west of the Cumberland Plateau escarpment in central Tennessee (Fig. 1, inset), and underlain by carbonate and siliclastic rocks of Mississippian age. That portion of the Highland Rim underlain by the St. Louis limestone typically forms a well-developed

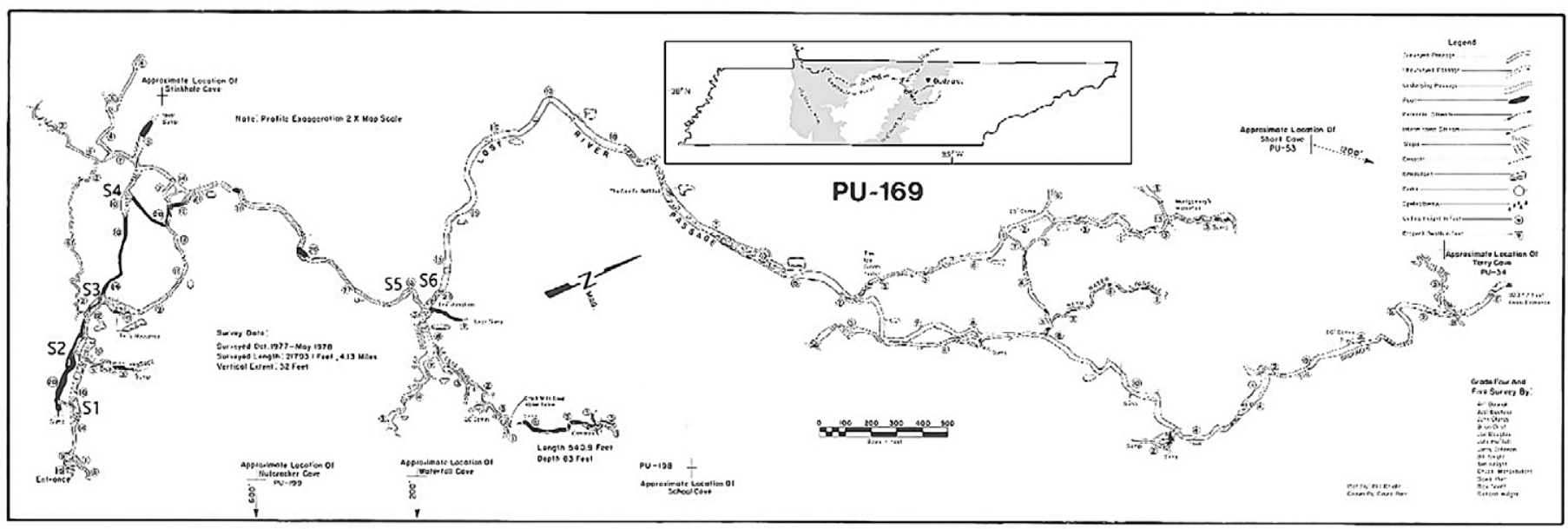

Figure 1. Map of Capshaw Cave showing sampling location S-4. Other sites with similar deposits are shown but were not sampled. The East Highland Rim, Tennessee (inset).

sinkhole plain, mantled with residual, clay-rich soils, and crossed by only a few surface streams. However, areas underlain by the siliclastic-carbonate Warsaw unit support a fluviokarst drainage network, with numerous sinking streams and resurgences. This study focuses on the stream in Capshaw Cave within the city limits of Cookeville, Tennessee (Fig. 1). The cave is formed in the middle portion of the Warsaw unit, has a $6.6 \mathrm{~km}$ total surveyed length, and consists of a borehole-type passage with diameters ranging from $4 \mathrm{~m}$ to $7 \mathrm{~m}$. Capshaw Cave ends in the downstream direction at a sump and apparent cave constriction. Dye tracing at the sump in Capshaw Cave showed a direct connection to a resurgent spring about $0.5 \mathrm{~km}$ downstream. The sump and the resurgence were also recently connected by a successful cave dive, which revealed that the cave constricts to a height of approximately $1.5 \mathrm{~m}$ at a point just downstream from the sump.

The watershed contributing to Capshaw Cave covers an area of approximately $8 \mathrm{~km}^{2}$ and was originally covered with hardwood forest before European settlement. After 1800, cropland and pasture began to replace forest cover. The population of Cookeville grew from 1848 in 1910 to 23,923 by 2000, which growth changed the watershed by increasing peak runoff from roads and parking lots, as well as introducing contaminants from roads and industry. A coal-burning powerplant was built in the watershed in 1929 and remained in operation until 2017. The Capshaw Cave watershed consists of approximately 39 percent impervious surfaces and thus has very flashy lag times, generally less than one hour, resulting in cave-filling floods (Hart, 2006). The cave is directly connected to the overlying watershed by a series of large swallets, some with conduit openings through which large amounts of sediment move into the cave during floods (Fig. 2) (Hart and Schurger, 2005). Capshaw Cave serves as the de-facto stormwater drain for the city of Cookeville, thus trash and debris from the city is commonly found in the cave. 


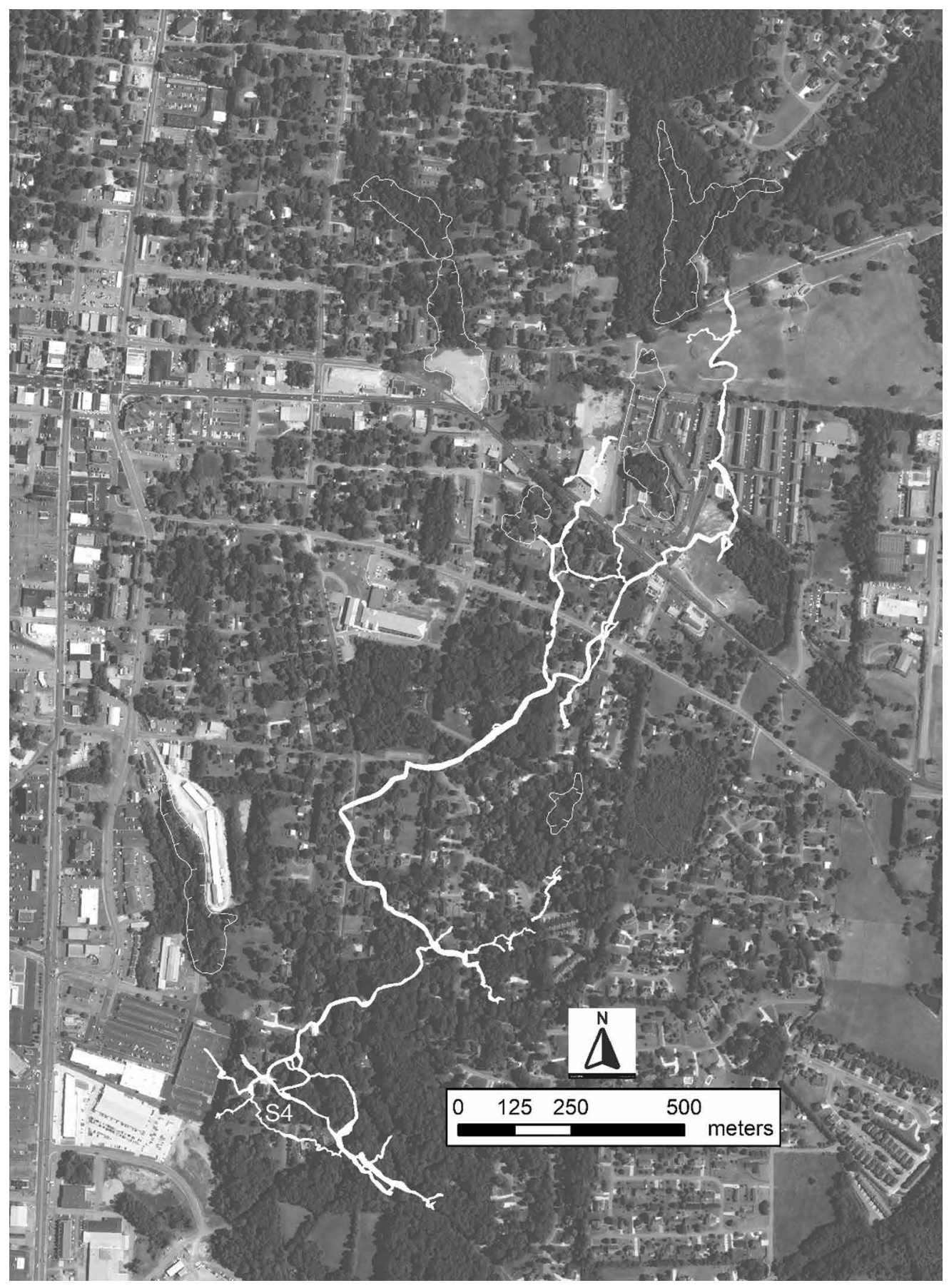

Figure 2. Aerial photograph of Cookeville, TN in 2017 showing location of Capshaw Cave and major swallets that drain into the cave. Cave stream runs from north to south, with sump at south end. Sampling location S-4 shown. laminations were too thin to be collected separately without mixing. It was possible to sample individually three of the thicker layers making a total of six (three light layers and three dark layers) at depths of $15 \mathrm{~cm}, 38 \mathrm{~cm}$, and $86 \mathrm{~cm}$. Mixed samples of both light and dark layers were also collected. For all samples, particle size distribution was determined by hydrometer analysis (Ashworth et al., 2001).

To establish the timing of the cave sediment deposition, additional box samples were collected directly from the sediment profile in $10 \mathrm{~cm}$ sections for chemical analysis. These samples were shipped to Flett Research Ltd, Laboratory, Winnipeg, Canada where ${ }^{137} \mathrm{Cs}$ activity was measured at each section mid-point $(5 \mathrm{~cm}, 15 \mathrm{~cm}$, etc.) by gamma spectrometry using high purity germanium detectors. Additional samples from site S-4 were also collected at $10 \mathrm{~cm}$ intervals (midpoints at $5 \mathrm{~cm}, 15 \mathrm{~cm}$, etc.) and tested for total elemental Pb concentration at the Tennessee Tech Univer- 


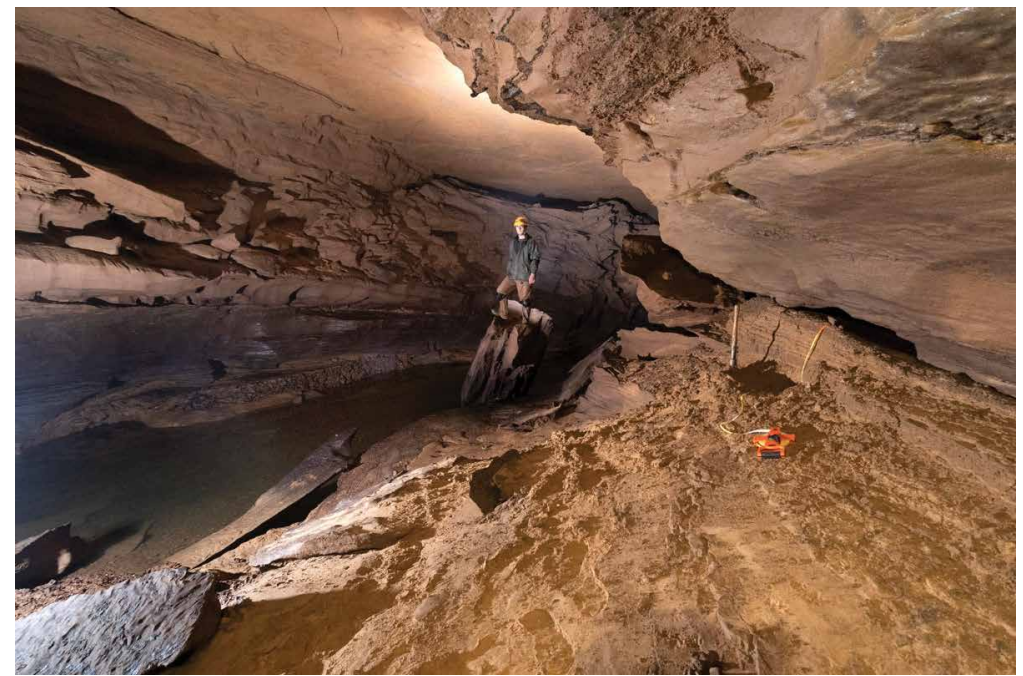

Figure 3. View of Capshaw Cave main passage showing cave stream and location of flood-deposited sediments to the right of stream channel. Photo taken near site S-6 in Figure 1.

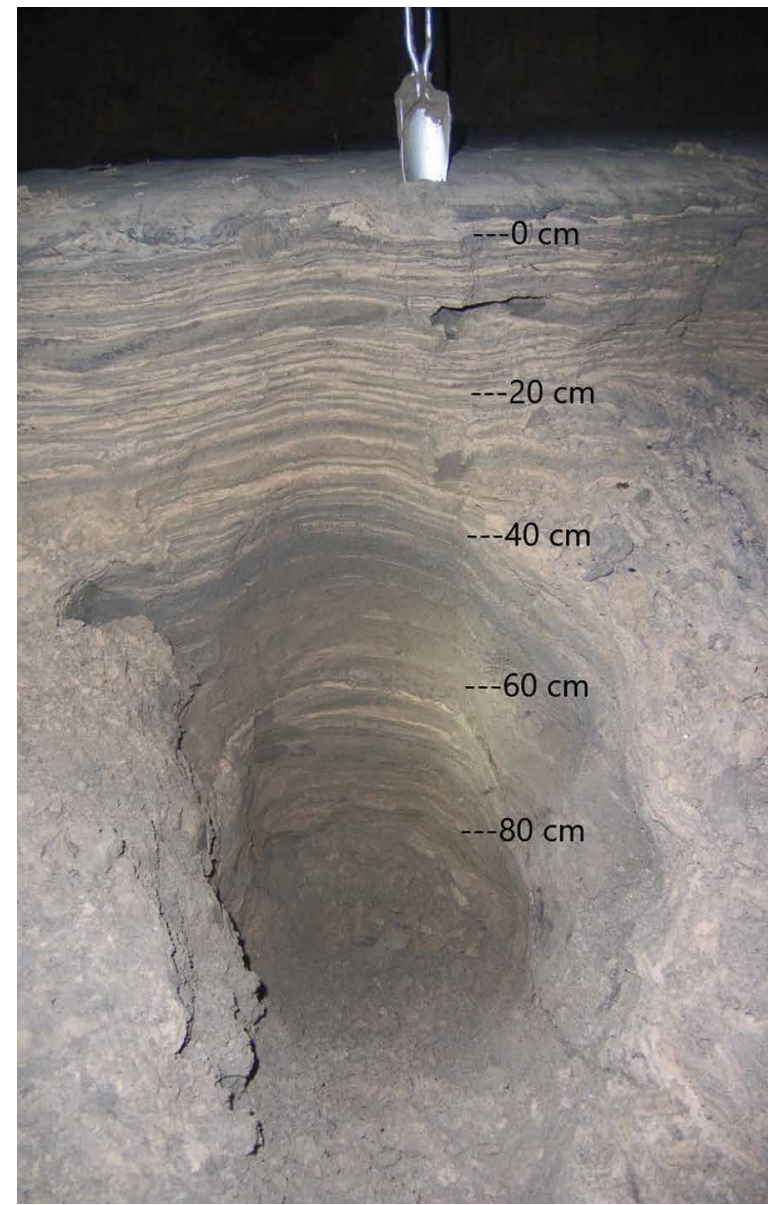

Figure 4. Sediment exposure at site S-4 in Capshaw Cave, showing alternating layers of fine sand (yellow) and silty sand (very dark grayish brown). Fine sand layers have average thickness of $0.5 \mathrm{~cm}$ in the upper $40 \mathrm{~cm}$ of the profile. Below $40 \mathrm{~cm}$, silty sand layers increase to 5 to $10 \mathrm{~cm}$ in thickness and are separated by only a few fine sand stringers. Only $80 \mathrm{~cm}$ of the entire $140 \mathrm{~cm}$ of sediment at this site is shown here. See Figure 5 for entire stratigraphic column of site S-4. sity Water Center using inductively coupled plasma atomic emission spectroscopy (USEPA, 1994). Total $\mathrm{Pb}$ concentration in lake sediments has been shown to track closely with the rise and fall of leaded gasoline use in the United States (Juracek and Ziegler, 2006). To shed light on the timing of cave sediment deposition, $\mathrm{Pb}$ concentrations measured in cave sediments in this study were compared to $\mathrm{Pb}$ emissions data from the 1900s, for which the timing is well-established. Recent sedimentation in the cave was measured by driving rebar pins vertically downward into the sediment and left for a period of two years. After flood events, the rebar stakes were checked to estimate the amount of deposition or re-working.

\section{RESULTS AND DISCUSSION}

\section{Character of the Sediment}

The alternating light and dark colored laminations at site S-4 have Munsell colors of 10Y 7/6 (yellow) and 10 Y 3/3 (very dark grayish-brown), respectively, and these colors are consistent throughout the deposit (Fig. 4). There is evidence of cross bedding and termination of layers, suggesting a complex depositional history and at least some degree of re-working of sediments. The rebar stake measurement at site S-4 indicated that approximately $0.6 \mathrm{~cm}$ of vertical accretion occurred between 2013 and $2015\left(0.3 \mathrm{~cm} \mathrm{y}^{-1}\right)$, but this was likely too short of a period to capture long-term trends.

A total of 23 alternating laminations in the upper $40 \mathrm{~cm}$ of the profile vary in thickness from $0.5 \mathrm{~cm}$ to $2.0 \mathrm{~cm}$ and alternate in dominant particle size between fine sand (yellow) and silty sand (very dark grayish-brown). The median particle size diameter for the fine sand samples is $0.2 \mathrm{~mm}$ and $0.08 \mathrm{~mm}$ for the silty sand (Fig. 5). Between $40 \mathrm{~cm}$ and $80 \mathrm{~cm}$, silty sand layers increase in thick-

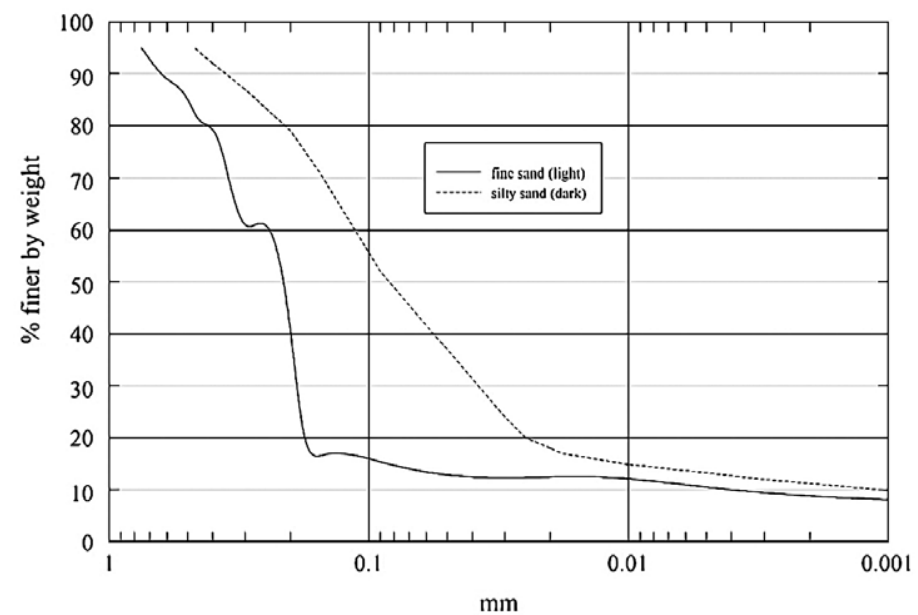

Figure 5. Plot of grain size frequency distribution for fine sand (yellow) and silty sand (very dark grayish brown) for cave sediment samples at site S-4. Three separate samples were collected from fine sand and silty sand layers at depths of $15 \mathrm{~cm}, 38 \mathrm{~cm}$, and $86 \mathrm{~cm}$. Data plotted are averages of these three samples taken from each dark and light layer that was sampled. The median particle size diameter varied from $0.2 \mathrm{~mm}$ for fine sand to $0.08 \mathrm{~mm}$ for silty sand. The theoretical settling velocities for fine sand $\left(2.0 \mathrm{~cm} \mathrm{~s}^{-1}\right)$ are 40 times greater than for silty sand $\left(0.05 \mathrm{~cm} \mathrm{~s}^{-1}\right)$. 


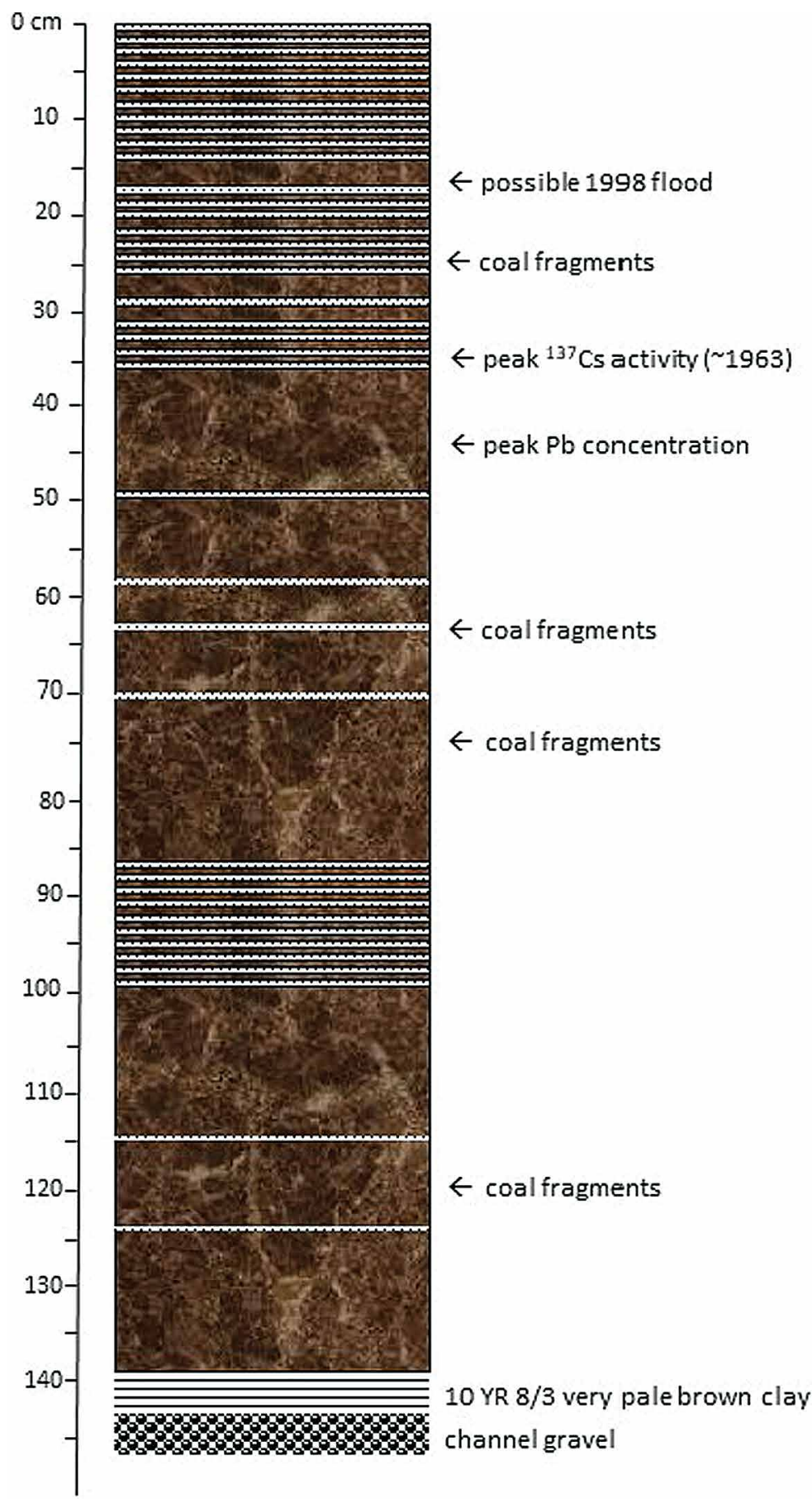

Figure 6. Generalized stratigraphic column for site S-4. Dark pattern shows $10 Y 3 / 3$ (very dark grayish brown) silty sand and light stippled pattern shows layers of $10 \mathrm{Y} 7 / 6$ (yellow) fine sand. Cross bedding and truncation of some layers does occur. Sediments above $35 \mathrm{~cm}$ were deposited after the $1963{ }^{137} \mathrm{Cs}$ peak fallout. Coal fragments found throughout the deposit come from anthropogenic sources that became abundant after 1900 . We interpret the $0 \mathrm{~cm}$ to $40 \mathrm{~cm}$ section to have more frequent flood events (note the many fine sand layers) and a lower sedimentation rate, both of which may result from urbanization. A $2 \mathrm{~cm}$ thick silty sand layer at $15 \mathrm{~cm}$ depth may represent an extreme flood event in 1998 that is known from the local area. From $40 \mathrm{~cm}$ to $140 \mathrm{~cm}$, floods appear less common and fine sand layers are missing. This pre-urban period likely had fewer cave-filling floods, but a greater rate of sedimentation, perhaps due to erosion from gullied farmland. Photo in Figure 4 shows the same site, but only down to $\sim 80 \mathrm{~cm}$. ness $(5 \mathrm{~cm}$ to $10 \mathrm{~cm})$ and are separated by only four $(<0.5 \mathrm{~cm})$ fine sand stringers (Fig. 6). This change in layer thickness may reflect changes in cave hydrology or changes in sediment availability within the cave, possibly associated with land use changes in the watershed. Between depths of $85 \mathrm{~cm}$ and $100 \mathrm{~cm}$, another set of approximately 10 fine sand stringers occur in close succession. From $100 \mathrm{~cm}$ to $140 \mathrm{~cm}$, the pattern again changes and the dark silty-sand layers increase in thickness and are separated by only four thin, fine sand layers. Finally, at a depth of $140 \mathrm{~cm}$ a firm 2.5 Y 8/3 (pale yellow) clay overlies channel gravels.

\section{SEDIMENTATION RATES AND FLOOD FREQUENCY}

Cesium-137 activity in the Capshaw Cave sediments shows a defined spike at approximately 35 $\mathrm{cm}$ depth and a steep decline below that point (Fig. 7A and Table 1). This pattern is consistent with ${ }^{137} \mathrm{Cs}$ activity measured in lake sediments across North America (Callender and Van Metre, 1997), and in other areas, and matches the peak atomic testing year of 1963. If this is the case, then the upper 35 $\mathrm{cm}$ of sediments were deposited after 1963, at a minimum rate of $0.7 \mathrm{~cm} \mathrm{y}^{-1}$. Background ${ }^{137} \mathrm{Cs}$ activity was reached at the $45 \mathrm{~cm}$ measurement, and so no further ${ }^{137} \mathrm{Cs}$ measurements were made on sediments below that level.

Total $\mathrm{Pb}$ concentrations from the Capshaw Cave sediments show an obvious spike at $0.15 \mathrm{mg} \mathrm{kg}^{-1}$ between $40 \mathrm{~cm}$ and $50 \mathrm{~cm}$ (Fig. 7B). All values for $\mathrm{Pb}$ concentrations reported here are below USEPA (1997) threshold level for possible adverse biological effects $\left(30.2 \mathrm{mg} \mathrm{kg}^{-1}\right)$. The entire total $\mathrm{Pb}$ curve matches well with the $\mathrm{Pb}$ emissions curve, which has a peak at around 1970 (USEPA, 2000) (Fig. 7C). This match between $\mathrm{Pb}$ concentration in the cave sediments and $\mathrm{Pb}$ emissions suggests that sediments can be dated based on the $\mathrm{Pb}$ emission curve. The timing of deposition suggested by $\mathrm{Pb}$ concentration tracks closely with the timing indicated by ${ }^{137} \mathrm{Cs}$ activity in the same sediments (Fig. 7A and 7B).

If each silty sand-fine sand sequence represents one flood event, then approximately 23 flood events are recorded in the upper $35 \mathrm{~cm}$ to $40 \mathrm{~cm}$ of sediments in Capshaw Cave. If the upper $40 \mathrm{~cm}$ was deposited between 1963 (the peak ${ }^{137} \mathrm{Cs}$ fallout) and 2013 (the sampling year), this would compute to a flood return interval of 2.2 years for cave-filling flood events. Between $40 \mathrm{~cm}$ and $85 \mathrm{~cm}$, only 4 fine sand stringers are found, suggesting that cave floods may have been less common before the 1960s; 

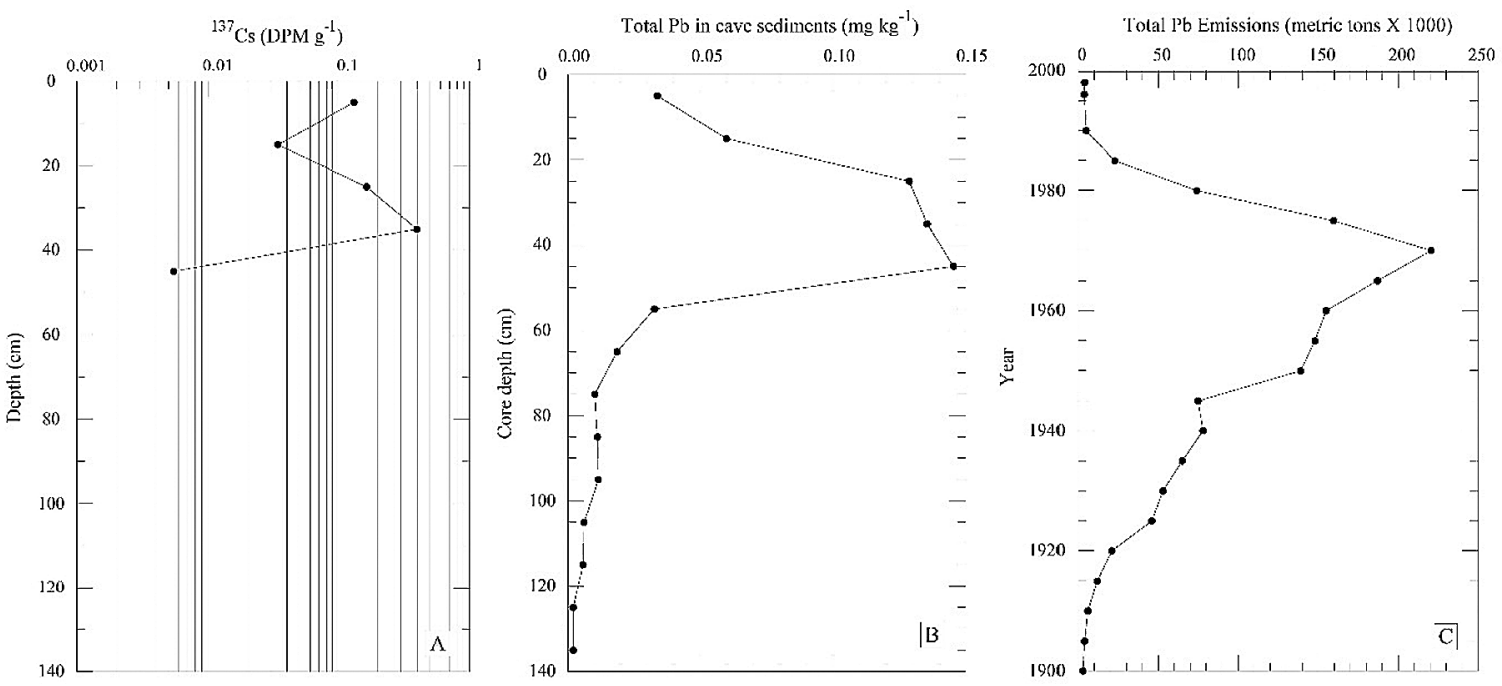

Figure 7. (A) Activity level of the fallout radionuclide ${ }^{137} \mathrm{Cs}$ in the Capshaw Cave sediment profile S-4. Measurements were made every $10 \mathrm{~cm}$ beginning at $5 \mathrm{~cm}$. Cesium-137 units are disintegrations per minute per gram (DPM $\left.\mathrm{g}^{-1}\right)$. The peak of atomic testing that released ${ }^{137} \mathrm{Cs}$ into the atmosphere occurred in 1963 and is shown to occur at approximately $35 \mathrm{~cm}$ in this profile. Background ${ }^{137} \mathrm{Cs}$ activity was reached at a depth of $45 \mathrm{~cm}$, and thus no further samples were tested below that depth. (B) Total $\mathrm{Pb}$ concentration measured in sediments at site $\mathrm{S}-4$, at $10 \mathrm{~cm}$ intervals beginning with $5 \mathrm{~cm}$ depth. (C) Total $\mathrm{Pb}$ emissions from all sources 1900 to 2000. Data after 1970 are from USEPA (2000) and data before 1970 are from Callender and Van Metre (1997). however, between $86 \mathrm{~cm}$ and $100 \mathrm{~cm}$ depth 10 fine sand layers are observed, indicating a short interval of more frequent floods (Fig. 6). There is no control on dating of sediments at this depth, so an approximate flood return interval cannot be calculated for these layers.

Sand-sized coal fragments are found throughout the Capshaw sediment profile S-4. Under mag-

Table 1. Data from ${ }^{137} \mathrm{Cs}$ measurements, Flett Research Ltd, Laboratory, Winnipeg, Canada where ${ }^{137} \mathrm{Cs}$ activity was measured at each section mid-point $(5 \mathrm{~cm}, 15 \mathrm{~cm}$, etc.) by gamma spectrometry using high purity germanium detectors. DPM is disintegrations per minute. ${ }^{137} \mathrm{Cs}$ activity is plotted on Figure 7A.

\begin{tabular}{|c|c|c|c|c|c|c|}
\hline $\begin{array}{l}\text { Sample depth } \\
\text { (cm) }\end{array}$ & $\begin{array}{l}\text { Dry ample } \\
\text { weight }(g)\end{array}$ & $\begin{array}{c}\text { Sample } \\
\text { thickness }(\mathrm{mm})\end{array}$ & $\begin{array}{c}\text { Count time } \\
\text { (sec) }\end{array}$ & $\begin{array}{l}\text { Gammas } \\
\left(\mathrm{min}^{-1} \mathrm{~g}^{-1}\right)\end{array}$ & $\begin{array}{c}{ }^{137} \mathrm{Cs} \text { Activity } \\
\text { (DPM g-1 dry weight) }\end{array}$ & $\begin{array}{c}\text { Error DPM } \\
\left(g^{-1}\right)\end{array}$ \\
\hline 5 & 7.837 & 2.475 & 240000 & 0.112571 & 0.132436 & 0.043704 \\
\hline 15 & 12.154 & 2.8 & 240000 & 0.028879 & 0.033975 & 0.064636 \\
\hline 25 & 5.996 & 1.575 & 240000 & 0.139525 & 0.164146 & 0.062376 \\
\hline 35 & 6.949 & 1.9 & 240000 & 0.338068 & 0.397726 & 0.091082 \\
\hline 45 & 9.065 & 2.425 & 240000 & 0.004679 & 0.005505 & 0.085876 \\
\hline
\end{tabular}

inifcation, coal fragments can be easily distinguished from quartz grains that make up most of the cave sediments. Coal does not occur naturally in this watershed and its likely source is a coal-burning power plant that was in operation between 1929 and 2016. When in operation, a large pile of coal sat in the open on the plant parking lot, located $1.5 \mathrm{~km}$ upstream from a swallet that feeds the cave. A small channelized stream runs behind the plant and leads directly to the swallet. Another source for coal could have heating of private homes, however, this source may not have produced a large enough volume of coal that would later be preserved in cave sediments. In either case, the presence of coal in the watershed does not extend back any earlier than approximately 1900, and so the presence of coal in cave sediments shows that deposition occurred sometime after 1900.

To summarize, ${ }^{137} \mathrm{Cs}$ activity indicates that the upper $35 \mathrm{~cm}$ of sediment was deposited after the decade of the 1960s, at an approximate rate of $0.7 \mathrm{~cm} \mathrm{y}^{-1}$. These sediments were likely deposited during floods with recurrence interval of approximately two years, assuming each flood layer represents one flood event. It is possible that sediments receiving ${ }^{137} \mathrm{Cs}$ fallout outside the cave, were then temporarily stored (in sinkholes, for example) before arriving in the cave at their present locations. However, the year 1963 marks the earliest possible period of deposition for sediments at the $35 \mathrm{~cm}$ depth. The total $\mathrm{Pb}$ concentration measured in cave sediments at site $\mathrm{S}-4$ provides good agreement that the upper $35 \mathrm{~cm}$ to $40 \mathrm{~cm}$ was deposited since the 1960s or 1970s. Finally, based on the presence of coal fragments, the entire sequence of sediments at site S-4 was likely deposited after 1900. If this timing is true, then deposition of sediment between $140 \mathrm{~cm}$ and $40 \mathrm{~cm}$ occurred at a rate no slower than $1.6 \mathrm{~cm} \mathrm{y}^{-1}$, which is more than twice the rate from 1963 to 2013 according to ${ }^{137} \mathrm{Cs}$ activity $\left(0.7 \mathrm{~cm} \mathrm{y}^{-1}\right)$. 


\section{INTERPRETATION OF FLOOD EVENTS FROM SEDIMENT LAYERS}

The median particle diameters for the fine sand $(0.2 \mathrm{~mm})$ and silty sand $(0.08 \mathrm{~mm})$ layers (Fig. 5$)$ correspond to an approximate settling velocity of $2.0 \mathrm{~cm} \mathrm{~s}^{-1}$ for the fine sand and $0.05 \mathrm{~cm} \mathrm{~s}^{-1}$ for the silty sand, a 40 -fold difference. These velocities indicate that fine sand and silty sand layers are deposited at different flood stages. The exact sequence of deposition is difficult to interpret without acquiring additional data, for example, direct measurement of water velocity during floods and cave passage geometry would be helpful. While a fining-upward sequence is thought to be typical in many flood deposits, observations in Capshaw Cave suggest another scenario. Evidence comes from the simple observation that fine sand layers are always found on top of the sediment banks in Capshaw Cave after a flood, indicating that it must be the last material deposited in a flood (for example, see the fine sand on the surface of Site-4 in Fig. 4). Based on these results, there is possibly more than one explanation for the nature of laminated sediments in Capshaw Cave.

As water rises in the cave from runoff, velocities increase quickly, and some re-working of sediment may occur. This re-working may be the cause of the cross bedding seen in some layers in Fig. 4. As the flood progresses, the rate of flow into the cave exceeds the discharge leaving the cave, due to the narrow downstream constriction below the sump. The constriction creates a damming effect and water is temporarily ponded in the cave, causing it to leave behind flotsam plastered on the cave ceiling that is regularly observed after floods. During these times of ponding and lower velocity, the finer silty sand is likely deposited. As the cave drains, velocities increase again and the fine sand is left behind, often as very thin stringers that may only partially cover the dark silty sand.

The above interpretation is speculative, but perhaps represents the best understanding of these particular cave sediments, and only applies to floods that fill the entire cave. Smaller floods that never reach pipe-full conditions would not necessarily have the same sequence of deposition. These smaller floods may also re-work some of the lower sediments, distorting the overall interpretation. Thus, due to the fact that the cave fills to different heights depending on flood volume, the assumption that each sequence of fine sand/silty sand layers represents one flood event may not be valid. It is possible that some layers are the result of multiple events. The fact that the dark, silty sand units are thicker below $40 \mathrm{~cm}$ may be the result of different cave hydraulics that existed previously, for example, a tighter constriction below the sump could cause ponding in the cave to last longer. However, it seems unlikely that the $5 \mathrm{~cm}$ to $10 \mathrm{~cm}$ thick silty sand layers like those seen below $40 \mathrm{~cm}$ in Figure 6 each represent one flood event. It may be that several flood events are represented in one of these thick silty sand layers, and the fine sand is missing either because it was reworked or was not available to be deposited at that time.

\section{CONCLUSIONS}

Laminated sediments found in Capshaw Cave have two distinct mean particle size populations that indicate deposition at different velocities. Truncated beds and cross bedding indicate that re-working of sediments does occur in the cave, however, the amount of re-working must be minor since the regular pattern of laminations is preserved (Fig. 4). Cesium-137 activity measured in the sediments shows a general trend of gradual vertical accretion at a rate of approximately $0.7 \mathrm{~cm} \mathrm{y}^{-1}$ from 1963 to 2013. The concentration of total $\mathrm{Pb}$ in the cave sediments tracks with the rise and fall of $\mathrm{Pb}$ emissions in the United States and corresponds generally to the timing of deposition indicated by ${ }^{137} \mathrm{Cs}$ activity. If each of the 23 fine sand/silty sand sequences between $0 \mathrm{~cm}$ and $40 \mathrm{~cm}$ represents one flood event, this equates to an average flood return interval of $\sim 2.2$ years. In the section from $40 \mathrm{~cm}$ to $80 \mathrm{~cm}$, only 4 fine sand layers are found between $5 \mathrm{~cm}$ to $10 \mathrm{~cm}$ beds of silty sand. This finding suggests that flooding was less frequent before the 1960s and has increased with the growth of urbanization. Changes in cave hydrology that affect the drainage rate of the cave could also have changed over this period. In addition, re-working of sediment and sediment availability may challenge the assumption that each layer was deposited by a separate flood event. Anthropogenic coal fragments found throughout the entire depth of the deposit at site S-4 show that these sediments were deposited after coal burning became common in the watershed, about 1900 based on historical records. The rate of sedimentation in Capshaw Cave appears to have declined after the 1960s, at the same time that cave floods became more common (Fig. 6). This could be the result of urban growth after the 1960s, which led to more runoff and flooding and less sediment erosion, as agricultural fields were replaced by pavement. Pre-1960s land use was primarily agriculture and early air photos (1939) show a landscape scarred by gullies, capable of producing large volumes of sediment. More detailed sedimentological analysis of sediments and more precise dating methods (e.g., ${ }^{7} \mathrm{Be}$ ) could aid in better understanding the nature of recent cave sediment deposition.

\section{ACKNOWLEDGMENTS}

Many thanks to John Pegram, Clinton Elmore, Annabelle Dempsey, Luke Hornby, and Chuck Sutherland for help in sample collection and photography. Photo in Figure 3 by Chuck Sutherland; photo in Figure 4 by Clinton Elmore. 


\section{REFERENCES}

Ashworth, J., Keyes, D., Kirk, R., and Lessard, R., 2001, Standard procedure in the hydrometer method for particle size analysis: Communications in Soil Science and Plant Analysis, v. 32, no. 5-6, p. 633-642. https://doi.org/10.1081/CSS-100103897

Asmerom, Y., Polyak, V.J., and Burns, S.J., 2010, Variable winter moisture in the southwestern United States linked to rapid glacial climate shifts: Nature Geoscience, v. 3, no. 2, p. 114-117. https://doi.org/10.1038/ngeo754

Badertscher, S., Borsato, A., Frisia, S., Cheng, H., Edwards, R.L., Tüysüz, O., and Fleitmann, D, 2014, Speleothems as sensitive recorders of volcanic eruptions-the Bronze Age Minoan eruption recorded in a stalagmite from Turkey: Earth and Planetary Science Letters, v. 392, p. 58-66. https://doi.org/10.1016/j.epsl.2014.01.041

Boch R., Cheng H., Spötl C., Edwards R.L., Wang X., and Häuselmann P., 2011, NALPS: a precisely dated European climate record 120-60 ka: Climate of the Past, v. 7, p. 1247-1259. https://doi.org/10.5194/cp-7-1247-2011

Bosch, R.F., and White, W.B., 2007, Lithofacies and transport of clastic sediments in karstic aquifers: in Sasowsky, I. and Mylroie, eds., Studies of Cave Sediments, Physical and Chemical Records of Paleoclimate, The Netherlands, Springer, p. 1-22. https://doi.org/10.1007/978-1-40205766-3_1

Brinkmann, R. and Reeder P., 1995, The relationship between surface soils and cave sediments: an example from west central Florida, USA: Cave and Karst Science, v. 22, no. 3, p. 95-102.

Broderick C.A., Wicks C.M., and Paylor R.L., 2017, Testing the effectiveness of Beryllium-7 as a tracer of the movement of sediment over short periods along a cave stream in Hidden River Cave, Kentucky U.S.A: Journal of Cave and Karst Studies, v. 79, no. 2, p. 84-88. https://doi. org/10.4311/2016ES0115

Bull, P.A., 1978, A study of stream gravels from a cave: Agen Allwedd, South Wales, Zietschrift für Geomorphologie, v. 22 , no. 3, p. $275-296$.

Bull, P.A., 1981, Some fine-grained sedimentation phenomena in caves, Earth Surface Processes and Landforms, v. 6, p. 11-22. https://doi. org/10.1002/esp.3290060103

Callender, E., and Van Metre, P.C., 1997, Reservoir sediment cores show U.S. lead declines: Environmental Science \& Technology, v. 31, p. 424A-428A. https://doi.org/10.1021/es972473k

Clark-Balzan, L.A., Candy, I., Schwenninger, J. L., Bouzouggar, A., Blockley, S., Nathan, R., and Barton, R.N.E., 2012, Coupled U-series and OSL dating of a Late Pleistocene cave sediment sequence, Morocco, North Africa: significance for constructing Palaeolithic chronologies: Quaternary Geochronology, v. 12, p. 53-64. https://doi.org/10.1016/j.quageo.2012.06.006

Curry, W., 2003, Using cesium-137 to understand recent in cave sedimentation in the Tongass National Forest, Southeast Alaska [M.S. Thesis]: Bowling Green, Western Kentucky University, $94 \mathrm{p}$.

Dogwiler, T., and Wicks, C.M., 2004, Sediment entrainment and transport in fluviokarst systems: Journal of Hydrology, v. 2951, p. $163-172$. https://doi.org/10.1016/j.jhydrol.2004.03.002

Drysdale, R., Zanchetta, G., Hellstrom, J., Maas, R., Fallick, A., Pickett, M., Cartwright I., and Piccini, L., 2006, Late Holocene drought responsible for the collapse of Old World civilizations is recorded in an Italian cave flowstone: Geology, v. 342, p. 101-104. https://doi.org/10.1130/ G22103.1

Feist, S.K., 2017, Investigation of sediment pathways in Hidden River Cave, Kentucky, [Ph.D. Thesis]: Hamilton, Ontario, McMaster University, 69 p. https://doi.org/10.1130/abs/2016NC-275204

Gillieson, D., 1986, Cave sedimentation in the New Guinea highlands: Earth Surface Processes and Landforms, v. 11, p. 533-543. https://doi. org/10.1002/esp.3290110508

Granger, D.E., Fabel, D., and Palmer, A.N., 2001, Pliocene-Pleistocene incision of the Green River, Kentucky, determined from radioactive decay of cosmogenic ${ }^{26} \mathrm{Al}$ and ${ }^{10} \mathrm{Be}$ in Mammoth Cave sediments: Geological Society of America Bulletin, v. 1137, p. 825-836. https://doi. org/10.1130/0016-7606(2001)113<0825:PPIOTG>2.0.CO;2

Hart, E.A., 2006, Land use change and sinkhole flooding in Cookeville, Tennessee: Southeastern Geographer, v. 46, p. 35-50. https://doi. org/10.1353/sgo.2006.0006

Hart, E.A., and Schurger, S.G., 2005, Sediment storage and yield in an urbanized karst aquifer: Geomorphology, v. 70, p. 85-96. https://doi. org/10.1016/j.geomorph.2005.04.002

Juracek, K.E., and Ziegler, A.C., 2006, The legacy of leaded gasoline in bottom sediment of small rural reservoirs: Journal of Environmental Quality, v. 356, p. 2092-2102. https://doi.org/10.2134/jeq2006.0128

Klimchouk, A.B., and Gudzenko, V.V., 1996, Chernobyl radiocaesium in a karst system, Marble Cave, Crimea: Environmental Geology, v. 283, p. 161-166. https://doi.org/10.1007/s002540050089

Mahler, B.J., Bennett, P.C., and Zimmerman, M., 1998, Lanthanide-labeled clay: a new method for tracing sediment transport in karst: Ground Water, v. 36, no. 5, p. 835-843. https://doi.org/10.1111/j.1745-6584.1998.tb02202.x

Mahler, B.J., and Lynch, F.L., 1999, Muddy waters: temporal variation in sediment discharging from a karst spring: Journal of Hydrology, v. 214 p. 165-178. https://doi.org/10.1016/S0022-1694(98)00287-X

McDermott, F., 2004, Palaeo-climate reconstruction from stable isotope variations in speleothems: a review: Quaternary Science Reviews, $v$. 237, p. 901-918. https://doi.org/10.1016/j.quascirev.2003.06.021

Meyer, M., Spötl, C., and Mangini, A., 2008, The demise of the Last Interglacial recorded in isotopically dated speleothems from the Alps: Quaternary Science Reviews, v. 27, p. 476-496. https://doi.org/10.1016/j.quascirev.2007.11.005

Modrá, H., Gruberová, E., Konečný, O., Ulmann, V., Kaucká, P., Vlková, M., Tůma, A., Halešová, T., Kudělka, J., Geršl, M., and Pavlík, I., 2017, Influx and concentration of triazine pesticides in the Amaterska cave system, Moravian Karst, Czech Republic: Journal of Soils and Sediments, v. 18, no. 2, p. 640-647. https://doi.org/10.1007/s11368-017-1831-0

Onac, B.P., Hutchinson, S.M., Geantă, A., Forray, F., Wynn, J., Giurgiu, A., and Coroiu, I., 2015, A 2500-y late Holocene multi-proxy record of vegetation and hydrologic changes from a cave guano- clay sequence in SW Romania: Quaternary Research, v. 83, p. 437-48. https://doi org/10.1016/j.yqres.2015.01.007

Poreba, G.J., 2006, Caesium-137 as a soil erosion tracer: a review: Geochronometria, v. 25, p.37-46.

Sasowsky, I.D., and Mylroie, J., 2007, Studies of Cave Sediments, Physical and Chemical Records of Paleoclimate: The Netherlands, Springer, 329 p. https://doi.org/10.1007/978-1-4020-5766-3

Sasowsky, I.D., White, W.B., and Schmidt, V.A., 1995, Determination of stream-incision rate in the Appalachian plateaus by using cave-sediment magnetostratigraphy: Geology, v. 235, p. 415-418. https://doi.org/10.1130/0091-7613(1995)023<0415:DOSIRI>2.3.CO;2

Schiegl, S., Goldberg, P., Bar-Yosef, O., and Weiner, S., 1996, Ash deposits in Hayonim and Kebara caves, Israel: macroscopic, microscopic and mineralogical observations, and their archaeological implications: Journal of Archaeological Science, v. 235, p. 763-781. https://doi. org/10.1006/jasc.1996.0071 
Spötl, C., and Mangini, A., 2002, Stalagmite from the Austrian Alps reveals Dansgaard-Oeschger events during isotope stage 3: Implications for the absolute chronology of Greenland ice cores: Earth and Planetary Science Letters, v. 203, p. 507-518. https://doi.org/10.1016/S0012$821 \times(02) 00837-3$

Šroubek, P., J.F. Diehl, J.F., and Kadlec, J., 2007, Historical climatic record from flood sediments deposited in the interior of Spirálka Cave, Czech Republic: Palaeogeography, Palaeoclimatology, Palaeoecology, v. 251, p. 547-562. https://doi.org/10.1016/j.palaeo.2007.05.001

Šroubek, P., Diehl, J.F., Kadlec, J., and Valoch, K., 2001, A Late Pleistocene palaeoclimatic record based on mineral magnetic properties of the entrance facies sediments of Kulna Cave, Czech Republic: Geophysical Journal International, v. 147, p. 247-262. https://doi.org/10.1046/ j.0956-540x.2001.01527.x

Stanton, R.K., Murray, A.S., and Olley, J.M., 1992, Tracing the source of recent sediment using environment magnetism and radionuclides in the karst of the Jenolan Caves, Australia: International Association of Hydrological Sciences Publication Number 210, p. 125-133.

Stock, G.M., Anderson, R.S., and Finkel, R.C., 2004, Pace of landscape evolution in the Sierra Nevada, California, revealed by cosmogenic dating of cave sediments: Geology, v. 323, p. 193-196. https://doi.org/10.1130/G20197.1

Surić, M., Juračić, M., and Horvatinčić, N., 2016, Comparison of ${ }^{14} \mathrm{C}$ and ${ }^{230} \mathrm{Th} /{ }^{234} \mathrm{U}$ dating of speleothems from submarine caves in the Adriatic Sea (Croatia): Acta Carsologica, v. 33, p. 239-248. https://doi.org/10.3986/ac.v33i2.302

Thompson, P., Schwarcz, H.P., and Ford, D.C., 1976, Stable isotope geochemistry, geothermometry, and geochronology of speleothems from West Virginia: Geological Society of America Bulletin, v. 87, p. 1730-1738. https://doi.org/10.1130/0016-7606(1976)87<1730:SIGGAG>2.0. $\mathrm{CO} ; 2$

USEPA, 1994, Method 200.7: Determination of metals and trace elements in water and wastes by inductively coupled plasma-atomic emission spectrometry: Revision 4.4, Cincinnati, $\mathrm{OH}$.

USEPA, 1997, The incidence and severity of sediment contamination in surface waters of the United States: Vol. 1, National Sediment Quality Survey. EPA/823/R-97/006. USEPA, Washington, DC.

USEPA, 2000, National air pollutant emission trends, 1900-1998: EPA/454/R-00/002. USEPA, Washington, DC: https://nepis.epa.gov/Exe/ ZyPDF.cgi/2000ETJA.PDF?Dockey=2000ETJA.PDF (accessed October 2019).

Walling, D.E. and He, Q., 1999, Improved models for estimating soil erosion rates from cesium-137 measurements: Journal of Environmental Quality, v. 282, p. 611-622. https://doi.org/10.2134/jeq1999.00472425002800020027x

White, W.B., 2007, Cave sediments and paleoclimate: Journal of Cave and Karst Science, v. 69, no. 1, p. 76-93.

Zhang, X.J., Zhang, G.H., Liu, B.L. and Liu, B., 2016, Using cesium-137 to quantify sediment source contribution and uncertainty in a small watershed: Catena, v. 140, p. 116-124. https://doi.org/10.1016/j.catena.2016.01.021 